IRA-International Journal of Management \& Social Sciences

ISSN 2455-2267; Vol.04, Issue 03 (2016)

Pg. no. 628-632

Institute of Research Advances

http://research-advances.org/index.php/RAJMSS

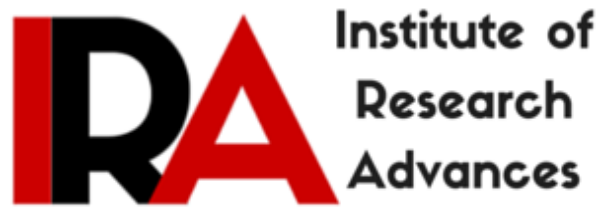

\title{
Forest Resources - An Ideal Alternative for Tribal Development and Health Care
}

\section{Shivesh}

Asst. Professor, M.B.A. Agri Business, RGSC, Banaras Hindu University, Varanasi, India.

Type of Review: Peer Reviewed.

DOI: http://dx.doi.org/10.21013/jmss.v4.n3.p13

\section{How to cite this paper:}

Shivesh. (2016). Forest Resources - An Ideal Alternative for Tribal Development and Health Care. IRA-International Journal of Management \& Social Sciences (ISSN 24552267), 4(3), 628-632. doi:http://dx.doi.org/10.21013/jmss.v4.n3.p13

(C) Institute of Research Advances

\section{(c) EY-NC}

This work is licensed under a Creative Commons Attribution-Non Commercial 4.0 International License subject to proper citation to the publication source of the work.

Disclaimer: The scholarly papers as reviewed and published by the Institute of Research Advances (IRA) are the views and opinions of their respective authors and are not the views or opinions of the IRA. The IRA disclaims of any harm or loss caused due to the published content to any party. 


\section{ABSTRACT}

The Indian sub-continent is inhabited by 53 million tribal populations belonging to over 550 tribal communities that come under 227 linguistic groups. They inhibit varied geographic and climatic Zones of the country. Their vocation ranges from hunting, gathering, cave dwelling nomadics to societies with settled culture living in complete harmony with nature. Forests have been their dear home and totally submitted themselves to forest settings. Their relationship with the forest was symbolic in nature. They have been utilizing the resources without disturbing the delicate balance of the eco-system. Tribals thus mostly remained as stable societies and were unaffected by the social, cultural, material and economic evolutions that were taking place with the so called civilized societies. But this peaceful co-existence of the tribals has been disturbed in recent years by the interference in their habitats. Traditional communities living close to nature have, over the years acquired unique knowledge about the use of living biological resources. Modernisation, especially industrialization and urbanisation has endangered the rich heritage of knowledge and expertise of age old wisdom of the traditional communities. A study on the utilization of local tribals revealed that they hold precious knowledge on the specific use of a large number of agents of wild plant and animal origins, the use of many are hitherto unknown to the outside world. The tribal people are the real custodians of the medicinal plants and thus by using their talents they can be developed as real custodian of Health Care in Indigenous field.

The present paper explains how medicinal the knowledge of medicinal plants can prove to be an ideal alternative for tribal development especially in the area of Health Care.

\section{Introduction}

The Indian sub-continent is inhabited by 53 million tribal populations belonging to over 550 tribalcommunities that come under 227 linguisticgroups. They inhibit varied geographic andclimatic Zones of the country. Their vocationranges from hunting, gathering, cave dwelling nomadics to societies with settled culture living incomplete harmony with nature. Forests have beentheir dear home and totally submitted themselvesto forest settings. Their relationship with the forestwas symbolic in nature. They have been utilizingthe resources without disturbing the delicatebalance of the eco-system. Tribals thus mostly remained as stable societies and were unaffectedby the social, cultural, material and economicevolutions that were taking place with the so calledcivilized societies. But this peaceful coexistence of the tribals have been disturbed in recent yearsby the interference in their habitats. Traditionalcommunities living close to nature have, over theyears acquired unique knowledge about the useof living biological resources. Modernisation, especially industrialization and urbanization has endangered the rich heritage of knowledge andexpertise of age old wisdom of the traditionalcommunities. A study on the utilization of local tribals revealed that they hold precious knowledge on the specific use of a large number of agents of wild plant and animal origins, the use of many arehitherto unknown to the outside world.

The tribalpeople are the real custodians of the medicinalplants. Out of 45,000 species of wild plants, 7500 species are used for medicinal purposes. 


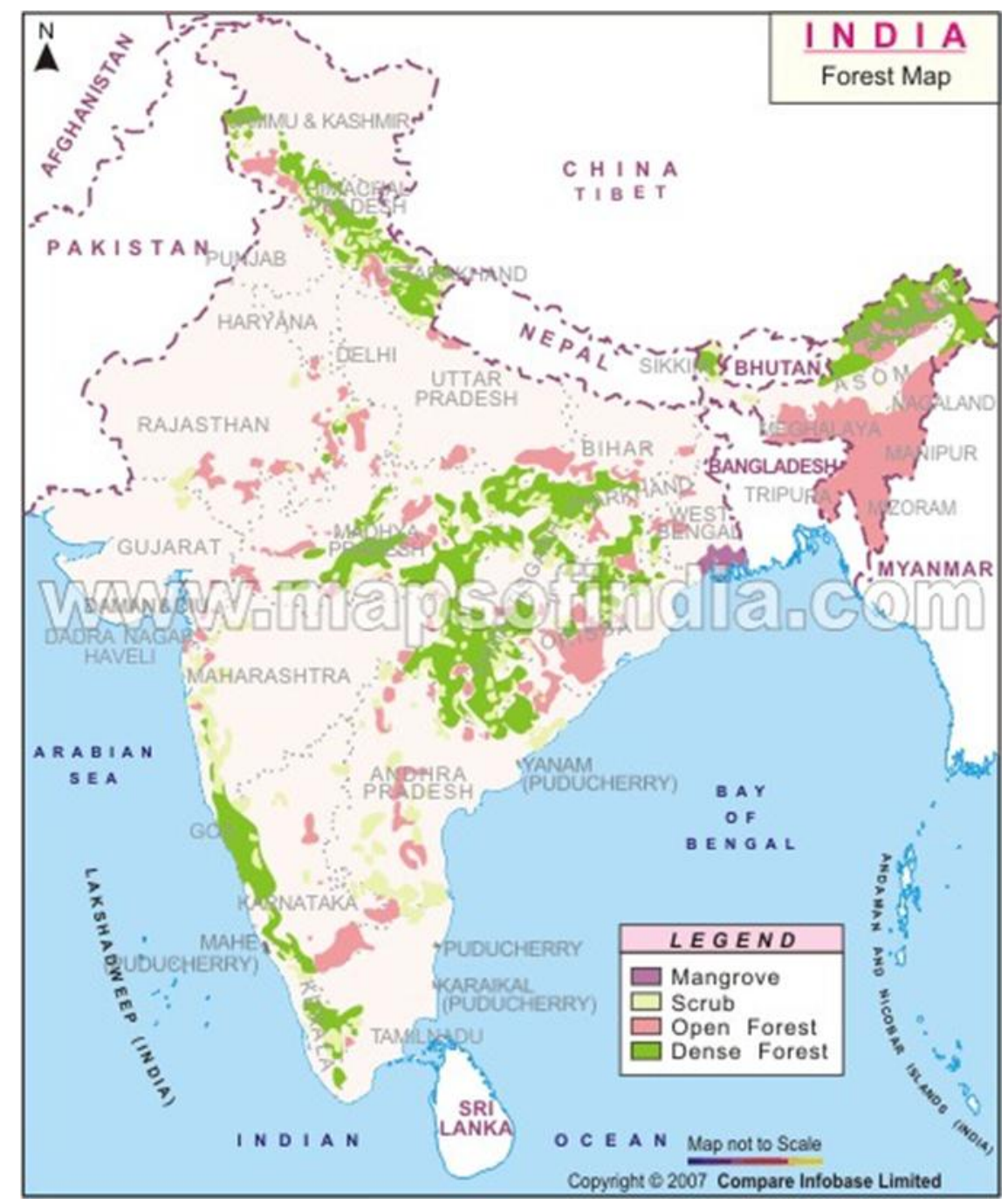

Fig Showing Forests Density on State Wise in India

The World Health Organisation (WHO) has been promoting a movement for 'Saving plantsfor saving lives'. This is because of the growingunderstanding of the pivotal role medicinal plantsplay in providing herbal remedies to healthmaladies. India is the home of several importanttraditional system of health care like Ayurveda.

This system depends heavily on herbal products.Several millions of Indian households have beenusing through the ages nearly 8000 species ofmedicinal plants for their health care needs. Overone and half million traditional healers use a widerange of medicinal plants for treating ailments ofboth humans and livestock across the length andbreadth of the country. Over 800 medicinal plantspecies are currently in use by the Indian herbalindustry. However, barring some 120 species, allothers are collected from the wild. This collectionoften involves destructing harvesting when partslike roots, bark, wood, stem and the whole plant (herb) are used. Unregulated wild harvest, alongside habitat loss and degradation is leadingto resource depletion which in turn is endangeringthe very survival of these species. No wonder, many of these species listed in the red data book of the IUCN and the Botanical Survey of Indiaare valued for their medicinal properties. 
The tribal people of Orissa have been inthe practice of preserving a rich heritage ofinformation on medicinal plants and their usage.

These people have faith in their traditional systemof health care and generally practice it. They have their own traditional physicians who use theseplants as their material medica. They have rich andoutstanding traditional knowledge and wisdomregarding material for healing of commonlyoccurring ailments. They have both the know-how and do-how for preparing the medicine and itsadministration. Unfortunately, this information isyet to be collected systematically andcomprehensively and maintained in databases in a manner they would help in protecting their IPR.

\section{Herbal History and Tradition in IndianContext:}

The Rigveda, the oldest document of human knowledge mentions the use of medicinal plants in the treatment of man and animals. Ayurveda gives the account of actual beginning of the ancient medical science of India, which according to western scholars was written between 2500 to 600 B.C. Charaka and Susruta wrote around 1000 B.C. Charaka concentrates more on medicine while Susruta deals with surgery in details along with therapeutics.After the invasion of India by the Greeks and Mohemmadans successively, the Indian system of medicine came to decline and no originalworks were then undertaken. During and afterthe British rule, there were two opinions, Onesupporting the rich treasure of knowledge ofIndian system of medicine and the other discardingit, calling it an old system based mainly onempiricism considering that this system hassurvived to such an extent the ravages of time, itcannot be brushed aside as "unscientific". It mightbe interesting to note that a large percentage,approximately $80 \%$ of the population of the worldstill relies on the old systems in some form or the other, and on the indigenous material medicinefor human and animal treatment, due to culturaltraditions and low buying capacity. When wecombine this economic factor with provenefficacy, our herbal drugs stand out as the betterchoice for millions. History shows that many of our important pharmacopial drugs were known and were also used in some form or the otherpossibly long before they were introduced intothe western medicine and before their actionswere investigated on scientific lines.

Measures to conserve biodiversity havebeen taken in India since hoary past. Elements ofthis aspect of traditional wisdom can be gatheredthrough analytical studies of the ethnic societieswhich are less influenced by the modern civilizationand also byscrutinizing the ancient texts written in sanskrit, pali, Tamil, etc. The Vishnu samhita is one of such scripture in Sanskrit language. Itappears that this work contains some directinstructions in connection with conservation of thebio-diversity.

According to the text of Vishnu samhita, causing any harm to the plant(s)/animal(s) is a sin.Even purloining of part(s)/ product(s) of any ofthese living beings is a crime. The sinner/criminalis liable to chastisement in this life and also after death. The punishment are of diverse nature :-pecuniary, corporal, expiatory and donation ofspecific article (s) to Brahmins. In this scripture there are some indirect instructions too, which canbe gleaned by analyzing the dietary regulationsand the use of bio-diversity in different religiousrites.

Traditional and folklore medicine bequeathed from generation to generation is rich in domestic recipes for common ailments. Traditional medicine encompasses protection andrestoration of health over millennia. The bestknown examples of Traditional medicine, differingin concept and protocol, are well developedsystems such as acupuncture and Ayurvedatreatments that have been widely used to sustainhuman health in India.

Developed countries, in recent times, areturning to use of herbal drugs and remedies.About 1400 herbal preparations are used widely, according to a recent survey in member states of European Union. Herbal 
preparations are popularand are of significance in primary health care inBelgium, France, Germany and the Netherlands.

Such popularity of plant derived products hasbeen traced to their increasing acceptance anduse in the cosmetic industries as well as to increasepublic costs in the daily maintenance of personalhealth and wellbeing. Examples of such beauty oriented therapeutically are skin tissue generators, anti wrinkling agents and anti-age creams. Alsoamong the poor, cures and drugs derived fromplants constitute the main source of health careproducts.

Despite the increasing use of medicinalplants, their future is being threatened bycomplacency concerning their conservation. Reserves of herbs and stocks of medicinal plantsin developing countries are diminishing severalimportant species are in danger of extinction as aresult of growing trade demands for safer andcheaper health care products and new plant based therapeutic markets in preference to moreexpensive targets-specific drugs and biopharmaceuticals.Such concerns have stimulatedaction in chronicling and conserving medicinal plants.

\section{References:}

- Anderson, Clifford R., Your guide to health, Orientalwatchman Publishing house (Pune,6th sept,2001)pp.644-712.

- Ambasta, S.P.(Ed.), The useful plants of India, Publications and information directorate(CS1R).

- Bakhru, H.K., Herbs that heal,Orient paperbacks, (NewDelhi, 1992).

- Chopra, Nayar, Chopra: Glossary of Indian Medicinalplants CSIR, (New Delhi,1956).

- Chiej, Roberto, The Macdonald encyclopaedia of Medicinal plants, maedonald and Company limited,(London, 1988).

- Das, Bhagwan, Fundamentals of Ayurvedic medicine, Konark publishers, (Delhi, 1989).

- Dastur, J.F., Medicinal Plants of India and Pakistan D. B. Taraporewala Sons Pvt. Ltd., (Mumbai,1988).

- Jain, S.K., Glimpses of Ethnobotany, National Book trustof India, A.S.Green Park, (New Delhi,1981), pp.7-270.

- Kar, A. \& Choudhary, B.K., Important mineral content of a few Ayurvedic herbs with a discussion on Medicinalaspects, Indian drugs. 31(3) -127-130.

- Khanna, G., All about herbal remedies, Vikal Publishing house, Pvt. Limited (New Delhi, 1994).

- Kloss, Jethro : Back to Eden, life line books, (California,1975).

- Nadkarni, K.M., Indian MateriaMedica, 3rd edition popular book dep., Bombay, 1954.

- Nayar, S.L. \& Chopra, I.C., Research in IndigenousDrugs, In Glossary of Indian medicinal Plants, CSIR, New Delhi, I-XI.

- Nagarjuna, S.et.al., Cultivation and utilization ofmedicinal plants, CSIR, (Jammu Tawi,1982), p.584-604

- Schultes, R.E. The role of Ethnobotanist in the search forthe new medicinal plants, 1962, Lioydia 25(4) : 257-266. 